\title{
CONTENTION IN CONTEXT
}





\title{
CONTENTION IN CONTEXT
}

Political Opportunities and

the Emergence of Protest

\author{
Edited by Jeff Goodwin \\ and James M. Jasper
}

Stanford University Press

Stanford, California 
Stanford University Press

Stanford, California

(ㅇ)2012 by the Board of Trustees of the Leland Stanford Junior University.

All rights reserved.

No part of this book may be reproduced or transmitted in any form or by any means, electronic or mechanical, including photocopying and recording, or in any information storage or retrieval system without the prior written permission of Stanford University Press.

Printed in the United States of America on acid-free, archival-quality paper

Library of Congress Cataloging-in-Publication Data

Contention in context : political opportunities and the emergence of protest / edited by Jeff Goodwin and James M. Jasper.

pages $\mathrm{cm}$

Includes bibliographical references and index.

ISBN 978-0-8047-7611-0 (cloth : alk. paper)--ISBN 978-0-8047-7612-7 (pbk. : alk. paper)

1. Social movements. 2. Protest movements. 3. Political science. I. Goodwin, Jeff, editor of compilation. II. Jasper, James M., 1957- editor of compilation.

HM881.C655 2011

$322.4--\mathrm{dc} 23$

2011026604

Typeset by Bruce Lundquist in 10/14 Minion 
In memory of Chuck Tilly 
